\title{
Managing Innovative Projects
}

\author{
Maphosa $\mathrm{M}^{1}$, Eloff $\mathrm{MM}^{2}$ \\ Institute for Corporate Citizenship, Unisa, South Africa \\ 1․mfowabo@gmail.com; ${ }^{2}$ eloffmm@unisa.ac.za
}

\begin{abstract}
Businesses and organisations are undertaking innovative projects to gain competitive advantage in the market. Research into innovative project management has been biased towards how innovative projects are managed to the detriment of the formulation of success criteria for innovative projects. There is a need to evaluate how innovative projects are managed. Project managers for innovative projects find it difficult to do so because success criteria for innovative projects have not been formulated. This paper is a theoretical study on managing different types of projects as different types of projects are managed in different ways. The paper also explores the characteristics of conventional projects as opposed to innovative projects and R\&D projects. In addition, it critically analyses the differences between project management in conventional projects and project management in innovative projects. By comparing the characteristics of conventional projects to those of innovative projects and R\&D projects, and the way these different types of projects are managed, the paper attempts to formulate success criteria for innovative projects that can be used by project managers to determine the success or failure of innovative projects.
\end{abstract}

Key Words - conventional projects, innovative projects, success criteria, critical success factors

\section{INTRODUCTION}

Since time immemorial, human beings have been known to undertake different kinds of projects. As project management has developed to suit the needs of the $21^{\text {st }}$ century, a new type of project known as innovative projects has emerged. Organisations embark on such types of projects to maintain or gain competitive advantage (Ireland \& Hitt, 1999).

Different types of projects are managed in different ways. Filippov \& Mooi (2010) suggested that innovation project management (IPM) should be studied as a distinct field separate from traditional project management, albeit using tools and methods of traditional project management. Few researchers have tackled the topic of IPM, which justifies why this research is worthwhile.

The area of innovation project management needs to be investigated further so that maximum benefits can be realised from innovative projects. According to Berggren, Järkvik \& Söderlund (2008) IPM constitutes a field of inquiry that requires constant research as firms and managers elaborate on new ways of organizing, of trying out new concepts, and of transferring ideas from one context to another to meet new challenges.

How are innovative projects different from other types of projects, if at all? This research paper attempts to answer this question by studying relevant literature on innovative projects and other types of projects. The paper aims to make a distinction between innovative projects and other types of projects. Lastly, the paper attempts to identify the required success criteria for innovative projects through a comparative analysis of other types of projects

Cozijnsen, Vrakking \& van ljzerloo (2000) note that few researchers have formulated success criteria for innovative projects with the majority only interested in discovering how innovative projects are conducted and managed. Project success in other types of projects can be easily measured according to existing and well defined success criteria. There is a need to formulate success criteria that can be used to evaluate innovative projects. 
The research approach is exploratory and involves a critical comparative analysis of conventional projects and innovative projects. This will be achieved by means of a literature study. The literature will encompass research articles, journals, conference proceedings and books. The research will identify the success criteria for the different types of projects as spelt out by various authors in literature.

The remainder of the paper is structured as follows: the next section contains a brief overview of the history and background of project management. The next section discusses project management in conventional projects followed by IPM. Lastly, the recommended success criteria for innovative projects are discussed, and recommendations are made based on the discussion.

\section{BRIEF OVERVIEW OF THE HISTORY AND BACKGROUND OF PROJECT MANAGEMENT}

When the term 'project management' was first used in the 1950s, the focus was on 'scheduling, budgeting and control. As project management developed, it has grown beyond scheduling, budgeting and control to encompass a wide range of fields such as operations management, risk management and systems thinking (Steyn, 2009).

Cozijnsen et al (2000) conducted an empirical study to determine how successful Dutch innovation projects were and what the success and failure factors of these innovation projects were. They found that the implementation phase had been ignored by researchers focusing on the success of phases that occur prior to the implementation phase. The authors also discovered that the success and failure factors of traditional projects had no influence on the success and failure of innovative projects. They concluded that these factors were dependent on the type of innovation. They were, however, unable to come up with conclusive statements on the relative importance of the success and failure factors in innovative projects.

As project management developed as a discipline, researchers and project managers became aware that meeting the iron triangle success criteria was simply not enough. Contrary to much earlier research the success of a project means meeting other criteria other than the triple constraint (Schwalbe, 2009). As researchers continue to study innovative project management, more success criteria for projects are emerging.

\subsection{What is a Project?}

A generalised definition of a project is that 'a project is an attempt to accomplish certain objectives by effectively organising the available resources to achieve the named objectives' (Turner 1999, Clements \& Gido, 2009). Projects are different from normal jobs or other routine tasks. Projects are non-routine while operations are routine; projects end when their objectives have been met or when the project has been terminated, whereas operations are the continuous tasks that sustain an organisation (Schwalbe 2009).

Table 1 below highlights the differences between a project and a business process. In practice the distinction is not so clear. Generally, a project has a distinct lifespan, a unique output and does not have any predefined work assignments.

Table 1: Getting started in project management (Martin \& Tate, 2001)

\begin{tabular}{|l|l|}
\hline \multicolumn{1}{|c|}{ Project } & \multicolumn{1}{c|}{ Business process } \\
\hline $\begin{array}{l}\text { Temporary: has a beginning } \\
\text { and an end }\end{array}$ & $\begin{array}{l}\text { Ongoing: The same process } \\
\text { is repeated over and over } \\
\text { again }\end{array}$ \\
\hline $\begin{array}{l}\text { Produces a unique output or } \\
\text { deliverable time }\end{array}$ & $\begin{array}{l}\text { Produces the same output } \\
\text { each time the process is run }\end{array}$ \\
\hline $\begin{array}{l}\text { Has no predefined work } \\
\text { assignments }\end{array}$ & $\begin{array}{l}\text { Has predefined work assign- } \\
\text { ments }\end{array}$ \\
\hline
\end{tabular}




\subsection{Classification of projects}

Filippov \& Mooi (2010) are of the opinion that there are two classes of projects namely innovation projects and conventional projects. This paper would base its arguments on their view. Figure 1 below shows the main types of projects that fall under innovation projects.

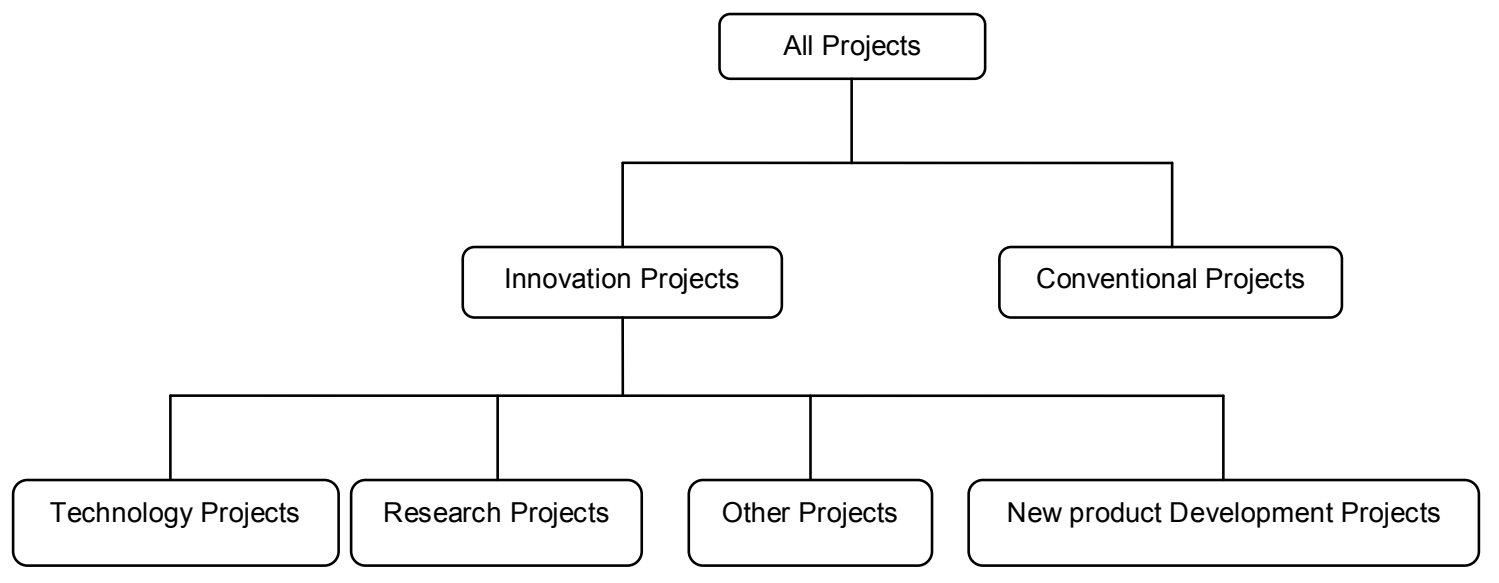

Figure 1: Classification of Projects (Filippov \& Mooi, 2010)

The authors differentiated innovative projects from conventional projects by noting that innovative projects should include at least one of the following criteria:

- $\quad$ Aimed at development of an innovative product/service

- Employs innovative methods and approaches

- $\quad$ Leads to the improvement of innovative and learning capabilities of the project executor

- $\quad$ Project must be realised in a close interaction with the project owner

\subsection{Project Success and Project Management Success}

Schwalbe (2009) identified the following ways of defining project success: the project's net scope, time and cost goals, if the project satisfied the customer/sponsor and if the results of the project met its main objectives. Project success is measured in terms of both efficiency (doing the thing right) and effectiveness (doing the right thing). In terms of efficiency, project success is achieved when a project is delivered on time and on budget. Efficiency is concerned with the project's processes, activities and resources. On the other hand effectiveness is achieved when the project's outcomes are met. Sadly most projects measure success in terms of efficiency only and not effectiveness (Nicholas \& Hidding, 2010). CookeDavies (2002), cited in Nicholas \& Hidding (2010) argues that efficiency results in project management success and effectiveness results in project success. Shokri-Ghasabeh \& Kavoousi-Chabok (2009) conducted a survey and found that more of professionals surveyed (46\%) believed that project success is totally different from project management success, while $43 \%$ indicated that they are the same.

\subsection{Critical Success Criteria and Critical Success Factors}

Critical success factors are important to an organisation as they help in successful implementation of projects. Cooke-Davies (2002) also tried to distinguish between success criteria and success factors. According to the author success criteria are the standards or methods used to determine success or failure of a project. Success factors are the project inputs that have a significant impact on the success of the project.

Shenhar \& Dvir (2007) argue that project success criteria should include strategic aims of the organisation. Rockart (1979), however, is of the opinion that critical success factors are the few areas that can result in competitive advantage for the organisation. Furthermore, the author states that these critical factors are the only areas that result in successful business operations. 
Dvir, Lipovetsky, Shenhar \& Tishler (1998) discovered that different types of projects have different success factors. They suggest that a more contingent approach be employed to project management theory and practice. This view is supported by Atkinson (1999) who suggests different ways of looking at project success criteria. Atkinson proposed three new categories based on the work of different researchers. The three categories were represented as 'The Square Route' to understanding project management success. He concludes that there are three other success criteria categories as suggested by a number of authors. The table below elaborates on what he considers to be the main components of each category.

Table 2: Project success criteria (Atkinson, 1999)

\begin{tabular}{|c|c|c|c|}
\hline $\begin{array}{c}\text { Iron } \\
\text { Triangle }\end{array}$ & $\begin{array}{c}\text { The information } \\
\text { system }\end{array}$ & Benefits (organisation) & $\begin{array}{l}\text { Benefits (stakeholder } \\
\text { community) }\end{array}$ \\
\hline $\begin{array}{ll}\text { - } & \text { Cost } \\
\text { - } & \text { Quality } \\
\text { - } & \text { Time }\end{array}$ & $\begin{array}{ll}- & \text { Maintainability } \\
\text { - } & \text { Reliability } \\
\text { - } & \text { Validity } \\
\text { - } & \text { Information quality } \\
& \text { use }\end{array}$ & $\begin{array}{ll}\text { - } & \text { Improved efficiency } \\
\text { - } & \text { Improved effectiveness } \\
\text { - } & \text { Increased profits } \\
\text { - } & \text { Strategic goals } \\
\text { - } & \text { Organisational-learning } \\
\text { - } & \text { Reduced waste }\end{array}$ & $\begin{array}{l}\text { - } \text { Satisfied users } \\
\text { - Social and Environmental } \\
\text { impact } \\
\text { - Personal development } \\
\text { - Professional learning } \\
\text { - } \text { Contractors profits }\end{array}$ \\
\hline
\end{tabular}

Rad \& Levin (2002) are of the opinion that project managers can create the success factors for their projects. The authors warn that the managers must be careful to identify and record these factors so that they can be referred to later even by the organisations running the projects. Understanding critical success factors can provide guidelines for project selection and can lead to valuable insight into the way projects can be managed (Belassi \& Tukel, 1996). They proposed a framework to classify critical success factors in four distinct groups, namely: factors relating to the project team, the project, the organisation and the external environment.

\section{PROJECT MANAGEMENT IN CONVENTIONAL PROJECTS}

Sauer \& Reich (2009) explore the changes in IT project management and the reasons for the changes. The authors tried to understand how leading project managers were managing IT projects to meet the growing demands of IT projects. It was found that changes in the IT project context also impact on the demands made upon project managers. These changes are the following:

- IT projects are no longer confined to the back-office but are so important because their success has a direct impact on the success of the entire organisation.

- Businesses are required to respond faster. Since IT projects affect business outcomes it is critical that more agile methods be used.

- Companies now seek a better return on investment (ROI) on IT project. IT projects are seen as investments.

- $\quad$ Clients have a better understanding of IT projects than before.

\subsection{Critical Success Factors in IT Projects}

Determining success and failure in projects is difficult to achieve because success/failure have different meanings to different people. Given the fact that sometimes success/failure can be difficult to measure, there is still the debate whether success /failure should be determined by comparing the results with the original estimates, revised estimates or industry performance benchmarks (Thomas \& Fernańdez, 2008).

Murray (2001) describes nine critical success factors that can either make or break IT projects. These factors are:

- Appropriate senior management levels of commitment to the project

- Adequate project funding

- A well-done set of project requirements and specifications

- Careful development of a comprehensive project plan that incorporates sufficient time and flexibility to anticipate and deal with unforeseen difficulties as they arise

- An appropriate commitment of time and attention on the part of those outside the IT department who 
have requested the project, combined with a willingness to see it through to the end

- Candid, accurate reporting of the status of the project and of potential difficulties as they arise

- A critical assessment of the risks inherent in the project, and potential harm associated with those risks, and the ability of the project team to manage those risks

- The development of appropriate contingency plans that can be employed should the project run into problems

- An objective assessment of the ability and willingness of the organization to stay the project course

Kimberling (2006) identified the following critical success factors for IT projects:

- Focus on business processes and requirements first

- Focus on achieving a healthy ROI, including post-implementation performance measurement

- Strong project management and resource commitment

- Commitment from company executives

- Take time to plan up front

- Ensure adequate training and change management

- Make sure you understand why you are implementing the project

\section{INNOVATION PROJECT MANAGEMENT}

\subsection{Innovation}

Innovation means different things to different people. Engineers perceive innovation to be a new product that has reached the market. Managers perceive innovation as the effort undertaken to create intentional change in an organisation. Even as far back as 1934 Schumpeter recognised that economically this change should lead to an increase in customer value or product value (Schumpeter, 1934).

According to Kavanagh \& Naughton (2009) innovation involves exploring and exploiting new to competitive advantage in an organisation. Boland \& Lyytinen (2007) argue that innovation is seen as a distributed phenomenon, characterised by messiness, ambiguity and non-linearity. Schumpeter (1934) describes innovation as 'gales of creative destruction' meaning that past innovations are revisited in light of changing dynamics.

Innovation can refer to both the innovation outcome itself as well as the process of achieving the innovation outcome (Robertson, Galliers, Ostrick \& Scarbrough, 2011). The most successful innovations result from a purposeful search by organisations other than flashes of genius (Drucker, 2002). As early as the 1930s, the phenomenon of innovation had attracted the attention of researchers, academics and scholars.

Berggren, Järkvik, Söderlund (2008) note that there is a close and important link between projects and innovation and introduce the theme of innovative approaches to project management. The authors state that 'project management in complex technology areas should not reflect but aim at controlling complexity: understand complexity, reduce complexity, and create mechanisms to make it possible to rapidly act on the consequences of complexity'.

According to the Oslo Manual (2005), the concept of innovation includes:

- Uncertainty over the results of the innovation activities

- Large investment in terms of both finance, time and technical expertise

- Innovation is subject to spill-overs

- Utilisation of new knowledge or a new use or combination of existing knowledge

- Innovation is carried out to achieve competitive advantage for the organisation 


\subsection{The Innovation Process}

The innovation process involves combining technical expertise and inventions to create a new product or service (Jain, Triandis \& Weick, 2010). The authors identified the following innovation process steps:

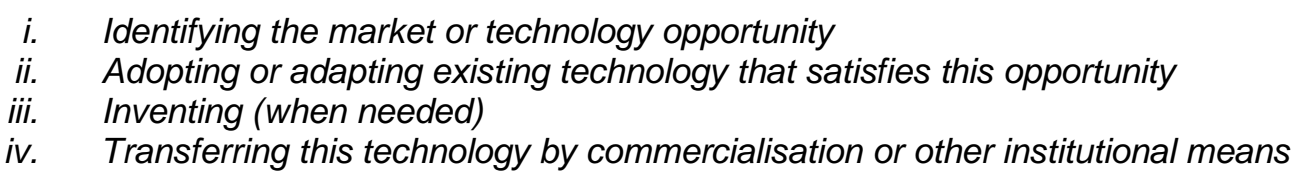

Furthermore, they also advocate that the innovative process is accomplished when the four steps above are integrated. They also note that in the first three steps, ideas and concepts are generated.

\subsection{Innovation project outcomes}

Jacoby \& Rodriguez (2007) suggest three basic models to explain innovation outcomes namely: incremental, evolutionary and revolutionary. Incremental innovation includes existing users and offerings. Figure 2 below shows the three innovation outcomes. As can be seen from the figure, incremental innovation includes existing users and offerings.

Evolutionary innovation includes existing users and new offerings or, new users and existing offerings. Revolutionary innovation includes new users and new offerings. The authors state that incremental innovations require people and processes possessing an execution focus. On the other hand, revolutionary innovations require people and processes possessing an exploration focus.

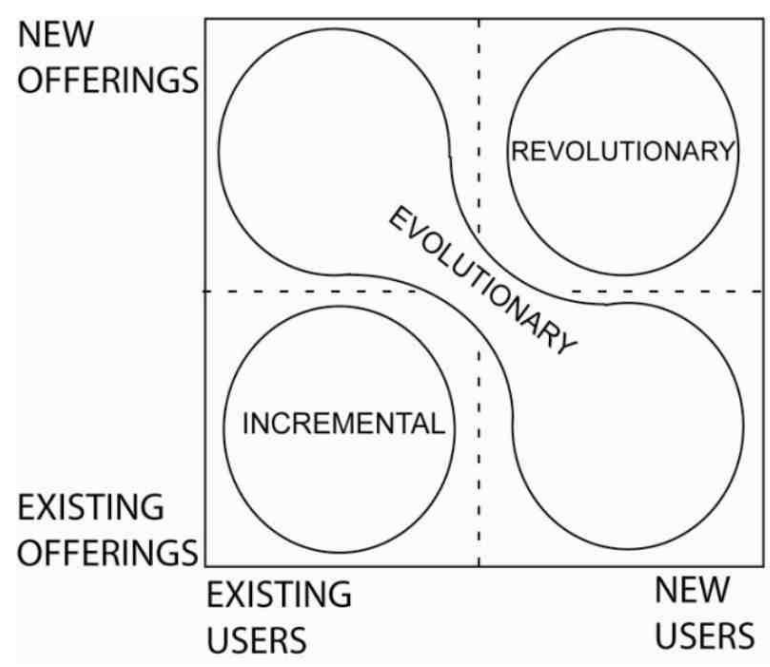

Figure 2: Innovation outcomes (Jacoby \& Rodriguez, 2007)

\subsection{Innovation versus invention}

According to Fagerberg (2004) invention is the process of generating ideas for new products or services while an innovation is the initial step of using the ideas in practice. There is a link between project management and innovation. Innovation is about incremental day to day expertise that is built through knowledge of customers and competitors. Project management prescribes rigid standards and techniques that can negatively affect the creativity needed to be innovative (Kavanagh \& Naughton, 2009).

Filippov \& Mooi (2010) state that an innovation project revolves around at least one of the following criteria:

- $\quad$ Aimed at development of an innovative (new) product or service

- Employ innovative methods or approaches

- Lead to improvement of innovative and learning capabilities of the project executor

- $\quad$ Be realised in a closed interaction with the project owner. 


\subsection{Open innovation versus closed innovation}

As innovation has been studied, two models of innovation have been proposed namely open innovation and closed innovation. According to Schroll \& Mild (2011) open innovation is characterized by 'its porous innovation process, and the strong interaction of the company with its environment. The authors also found that open innovation complements the $R \& D$ for the company'. Chesbrough (2003) defines closed innovation as a process in which 'successful innovations require control and firms have to be self-reliant because they cannot be certain of the quality, availability and capacity of other stakeholders'.

\subsection{Critical success factors for innovative projects}

Besner \& Hobbs (2008), state that an innovative project is a project that produces a new product or that involves a new concept and a new technology. Lechler \& Grace (2007) conducted research to find out if managing urgent and innovative projects differs from managing conventional projects. The research was conducted on data from 192 diverse projects in the United States. The authors recommended that innovative projects should be managed differently from conventional projects. They advocate for the following success factors as critical in innovative projects:

- Active top management support

- Strong leader communication

- Communication

Tidd, Bessant \& Pavitt (2001) argue that the following factors are necessary to stimulate innovation within organisations.

- Visionary leadership

- Appropriate organisational structure

- Recruitment of staff with necessary skills

- Willingness to be involved in innovation

- Effective and efficient team

- Organisation that is externally focused and exhibits extensive communication channels

- Organisation must be prepared to learn

\section{RESEARCH AND DEVELOPMENT (R\&D) PROJECTS}

Bogliacino \& Pianta (2010) investigated the relationship between innovative projects and R\&D projects. They noted that R\&D projects were the main input in innovative projects and that R\&D are the major drivers of innovation in organisations. Research and Development (R\&D) is creative work undertaken systematically to increase the stock of knowledge, including knowledge of humanity, culture and society and the use of this knowledge to devise new applications (OECD, 1993). According to the Oslo Manual (2005), while R\&D projects play a vital role in the innovation process, much process activity is not R\&Dbased, yet relies on highly skilled workers, on interactions with other firms and public research institutions, and on organisational structure that is conducive to learning and exploiting knowledge.

Cooper (2006) emphasizes that R\&D projects are different from other types of projects in that the scope, time, cost and quality cannot be determined beforehand. The author is of the view that using the traditional project management techniques on R\&D and innovative projects is not advisable as R\&D and innovative projects are complex, pose high-risk with lots of technical uncertainties.

\subsection{Types of Research Projects}

The National Science Board (2008) identifies 3 types of research projects.

- Basic research

Basic research is conducted to achieve an in depth knowledge or understanding of a specific subject matter without a specific application in mind.

- Applied research 
Applied research is directed toward gaining knowledge or understanding that can then be used in a specific application to meet recognised needs. In industry, applied research includes investigations aimed at new knowledge or understanding that leads to discovering new scientific knowledge.

- Development

Development is the application of knowledge or understanding obtained from basic and applied research to produce products or services. Development also includes the design development of prototypes and processes.

\section{DISCUSSION}

Innovative projects and R\&D projects are almost similar. Filippov \& Mooi (2010) classified research (R\&D) projects as a type of innovative projects. R\&D projects involve some degree of innovation. Table 3 contrasts innovative and R\&D projects.

Table 3: Differences between Innovative and R\&D Projects

\begin{tabular}{|l|l|l|}
\hline & \multicolumn{1}{|c|}{ Innovative Projects } & \multicolumn{1}{c|}{ R\&D Projects } \\
\hline Main focus of the projects & $\begin{array}{l}\text { Exploration and exploitation of new } \\
\text { ideas }\end{array}$ & $\begin{array}{l}\text { Increasing the knowledge of } \\
\text { humanity }\end{array}$ \\
\hline $\begin{array}{l}\text { Purpose for undertaking the } \\
\text { projects }\end{array}$ & $\begin{array}{l}\text { Making profit for the sponsoring } \\
\text { organisation }\end{array}$ & Advancement of knowledge \\
\hline $\begin{array}{l}\text { Where the projects are con- } \\
\text { ducted }\end{array}$ & Private companies or organisations & $\begin{array}{l}\text { Universities and research } \\
\text { institutions }\end{array}$ \\
\hline Who benefits from the projects & $\begin{array}{l}\text { The organisation that funded the } \\
\text { project }\end{array}$ & General public \\
\hline
\end{tabular}

By closely examining the definitions of the two, some differences emerge. Innovative projects involve exploration and exploitation of new ideas, while R\&D projects are concerned with increasing the knowledge of humanity and using this knowledge to improve products or services (OECD, 1993; Kavanagh \& Naughton, 2009). It is clear that these projects are driven by different motives. Innovative projects are undertaken for profits for the sponsoring organisation while R\&D projects are undertaken for the advancement of knowledge.

Another difference between innovative projects and R\&D projects lies on where these projects are conducted and who benefits from their results. Edquist (2010) states that R\&D projects are conducted mainly in universities and research institutions, and innovative projects are carried out by private companies or organisations. R\&D projects therefore benefit the general public because the findings become public knowledge. On the other hand, innovative projects only benefit the organisation that funded the project.

\subsection{Comparison of innovative projects and conventional projects}

Having clearly shown the differences between innovative projects and R\&D projects, we can now focus on comparing innovative projects with conventional projects. Both conventional projects and innovative projects are undertaken by private organisations. These organisations are usually experts in their fields and have some considerable expertise on the subject nature of the project being undertaken.

IT projects differ from other projects and have clear objectives with medium to high uncertainty. Hardware types of IT projects can have definite project durations although software projects are rarely completed on time, mainly because of the complexity involved. Project progress can be visible or invisible depending on the type of project. IT project risks are known but are difficult to manage.

R\&D projects differ from other projects due to high uncertainty related to scope, time, cost and quality. Because the objectives are unclear, it is difficult to estimate project duration and cost. R\&D projects also require huge financial investment and are usually funded by governments. Project progress is usually invisible and project risks are unknown and difficult to manage. 
Conventional projects are identified by any one of the following characteristics: clearly defined scope, stationery target and low and well understood risks and are based on linear thinking. Innovative projects, on the other hand, are identified by any one of the following characteristics: highly complex and may require a technical breakthrough, high risks, driven more by the project's end value than by the triple constraint (Kerzner \& Belack, 2010).Just like R\&D projects, innovative projects have high uncertainty. However, the objectives are relatively clear as organisations are aware of what they want to accomplish. It is quite difficult to estimate project duration and costs. Innovative projects require a relatively large financial investment. Risks are high and the organisation risks losing the finances invested on the project if the innovation is unsuccessful.

The table below summarises some of the comparative analysis of IT projects, R\&D projects and innovative projects.

Table 4: Critical comparative analysis of different types of projects

\begin{tabular}{|c|c|c|c|}
\hline & - IT projects & - R\&D projects & - Innovative projects \\
\hline $\begin{array}{l}\text { Project } \\
\text { features }\end{array}$ & $\begin{array}{l}\text { - Medium to high uncertainty } \\
\text { - Clear objectives } \\
\text { - Definite project duration } \\
\text { - Definite cost estimation } \\
\text { - Progress can be visible or } \\
\text { invisible }\end{array}$ & $\begin{array}{l}\text { - High uncertainty } \\
\text { - Unclear objectives } \\
\text { - Indefinite project duration } \\
\text { - Indefinite cost estimation } \\
\text { - Large financial investment } \\
\text { - Progress is invisible }\end{array}$ & $\begin{array}{l}\text { - High uncertainty } \\
\text { - Relatively clear objectives } \\
\text { - Indefinite project duration } \\
\text { - Indefinite cost estimation } \\
\text { - Large financial investment } \\
\text { - Progress is invisible }\end{array}$ \\
\hline Risks & $\begin{array}{l}\text { - Known but are difficult to } \\
\text { manage. }\end{array}$ & $\begin{array}{l}\text { - Unknown and difficult to } \\
\text { manage. }\end{array}$ & $\begin{array}{l}\text { - Unknown and difficult to } \\
\text { manage. }\end{array}$ \\
\hline $\begin{array}{l}\text { Success } \\
\text { criteria }\end{array}$ & $\begin{array}{l}\text { - Senior management } \\
\text { commitment } \\
\text { - Adequate project funding } \\
\text { - Project requirements and } \\
\text { specifications } \\
\text { - Comprehensive plan } \\
\text { - Commitment from all } \\
\text { - Accurate reporting } \\
\text { - Critical assessment of the } \\
\text { risks } \\
\text { - Contingency plans } \\
\text { - Assessment of the } \\
\text { organization to stay the } \\
\text { project course }\end{array}$ & $\begin{array}{l}\text { - Cost } \\
\text { - Time } \\
\text { - Quality } \\
\text { - Customer satisfaction } \\
\text { - Management support } \\
\text { - Service } \\
\text { - Innovation }\end{array}$ & $\begin{array}{l}\text { - Visionary leadership } \\
\text { - Appropriate organisational } \\
\text { structure } \\
\text { - Staff with necessary skills } \\
\text { - Willingness to be involved } \\
\text { in innovation } \\
\text { - Effective and efficient team } \\
\text { - Organisation with proper } \\
\text { - Lemmunication channels } \\
\text { - Learning organisation }\end{array}$ \\
\hline
\end{tabular}

Using traditional project management techniques to manage R\&D projects and innovative projects is not appropriate because R\&D projects and innovative projects involve a lot of risk, have a lot of unknowns and technical uncertainties (Cooper, 2006). Before doing a comparative analysis of innovative projects and conventional projects, it is important to note that the distinction is based on a generalisation of both innovative projects and conventional projects.

The table below shows the general differences between innovative projects and conventional projects. As can be seen from the table the two types of projects are different, therefore requiring different management approach.

Table 5: Comparative analysis of innovative project management and conventional project management

\begin{tabular}{|l|l|l|}
\hline Characteristics & Innovative projects & Conventional projects \\
\hline Starting point & $\begin{array}{l}\text { Projects embark from a loosely defined } \\
\text { area. }\end{array}$ & Projects start from a set of settled goals. \\
\hline Objectives & $\begin{array}{l}\text { Are ambiguous and become clearer as } \\
\text { the project progresses. }\end{array}$ & Have clearly defined objectives. \\
\hline
\end{tabular}




\begin{tabular}{|l|l|l|}
\hline Processes & Are more experimental and exploratory. & $\begin{array}{l}\text { Are more structured and follow strict } \\
\text { linear guidelines. }\end{array}$ \\
\hline Elusiveness & $\begin{array}{l}\text { Innovation projects are elusive and } \\
\text { cannot be described before being } \\
\text { achieved. }\end{array}$ & $\begin{array}{l}\text { Conventional project end products can be } \\
\text { defined from the onset. }\end{array}$ \\
\hline $\begin{array}{l}\text { Tools and tech- } \\
\text { niques }\end{array}$ & $\begin{array}{l}\text { Few tools and techniques are available } \\
\text { for managing innovative projects. }\end{array}$ & $\begin{array}{l}\text { Lots of tools and techniques make the } \\
\text { process of managing conventional } \\
\text { projects more effective. }\end{array}$ \\
\hline Project vision & $\begin{array}{l}\text { Team must create a shared vision for the } \\
\text { innovative product or service. }\end{array}$ & $\begin{array}{l}\text { Project vision in conventional projects is } \\
\text { created by the project sponsor. }\end{array}$ \\
\hline Guidelines & $\begin{array}{l}\text { Few guidelines are available for } \\
\text { innovation project management. Initial } \\
\text { stages of projects are more experiential } \\
\text { and exploratory. }\end{array}$ & $\begin{array}{l}\text { Conventional project management follows } \\
\text { a set of guidelines. }\end{array}$ \\
\hline Risk & $\begin{array}{l}\text { Risk and failure are built-in possibilities for } \\
\text { innovative projects. Risk taking is high. }\end{array}$ & $\begin{array}{l}\text { Risks are easy to define in conventional } \\
\text { projects. Risk taking is low. }\end{array}$ \\
\hline $\begin{array}{l}\text { Risk manage- } \\
\text { ment }\end{array}$ & $\begin{array}{l}\text { Project team is more active in risk } \\
\text { management. }\end{array}$ & $\begin{array}{l}\text { Project team is less active in risk manage- } \\
\text { ment. }\end{array}$ \\
\hline Project team & $\begin{array}{l}\text { More diverse and have a higher level of } \\
\text { trust. }\end{array}$ & $\begin{array}{l}\text { Project team made up of people from the } \\
\text { same industry and there is a low level of } \\
\text { trust. }\end{array}$ \\
\hline $\begin{array}{l}\text { Project } \\
\text { expenses }\end{array}$ & $\begin{array}{l}\text { Are usually long-term, with increased } \\
\text { insecurity as the project progresses. }\end{array}$ & Are easy to define and to track. \\
\hline
\end{tabular}

\section{RECOMMENDATIONS AND CONCLUSION}

Researchers and authors have noted that it is difficult to quantify innovative project success based on external success criteria. Each organisation that undertakes an innovative project must come up with its own goals. These goals are used to measure the success of the project (Cozijnsen et al, 2000). This makes it difficult to use empirical evidence from different innovative projects to come up with success criteria.

There is definitely a need to propose new success criteria for innovative projects. Bogliacino \& Pianta (2010) argued that R\&D projects are major drivers for innovation. By looking closely at the success criteria for R\&D projects and innovative projects, we can come up with new success criteria for innovative projects.

Innovative projects exhibit a high level of uniqueness which makes coming up with success criteria that can be used on them challenging. The critical comparative analysis of the different types of projects indicates that management support is an important success criterion in all the three types of projects studied in this paper. The researcher postulates that the most important success criterion for innovative projects is top management support. Top management must support the organisation not just by committing the resources of the organisation but by also actively guiding and supporting the project team.

The composition of the innovation project team is also an important success criterion. The project team must be efficient and effective and should possess the necessary technical expertise in the field in which the project is being undertaken. Furthermore, innovative projects need strong project management skills. This means that when compared to conventional project managers, innovative project managers must have extra technical knowledge and skills to provide effective coordination of all planning and implementation activities.

Communication is the lifeline of organisations. For an projects to operate effectively there should be healthy communication amongst team members. It is therefore important that appropriate communication channels be utilised within the project team. By using appropriate communication channels, all team members can have access to project information when they need to. 
Innovative projects are complex because of unclear objectives. Before an organisation undertakes an innovative project it must try to define, albeit vaguely, the objectives of the project. This will help in spelling out the project requirements and specifications. These will, without doubt, guide the project team and assist them or risk experts to come up with a critical assessment of project risks.

The iron triangle of success criteria also applies to innovative projects. Cost is important in the sense that no organisation would want to invest money into an innovative project if it would not result in a competitive advantage for the organisation. Quality means that the output of the project should meet the minimum specifications.

Without doubt, all projects, including innovative projects, need to be completed on time. Time is important because if a project goes on indefinitely, the organisation would lose the competitive advantage that it would have realised from the output of the innovative project. Private organisations that undertake innovative projects have competitors, hence the need to complete projects on time.

Quality, time and cost are important success criteria for both innovative and conventional projects. Over and above quality, time and cost, our analysis of literature shows that the following are important success criteria for innovative projects.

- Top management support

Top management support is critical for innovative projects because top management "mediates, interprets and buffers the market's needs and allocates the organisation's resources" (Splender \&Kessler, 1995).

- Project team

The project team must be efficient and effective and should possess the necessary technical expertise in the field in which the project is being undertaken

- Communication

Communication among the project team members is important. Mayfield \& Mayfield (2004) recommended a variety of communication techniques to be used in innovative project teams.

- Clear project requirements and specifications

Innovative projects always involve higher uncertainty and risk of non-compliance with the project objectives (Korecky\& Trkovsky 2009). It is therefore essential that clear objectives and specification are drawn for innovative projects.

- Strong project manager

The project manager should be a strong communicator. Splender \& Kessler (1995) argue that having a strong communicator offers some benefits for the project.

- Risk management

Without doubt risks are a natural part of every innovation project. For innovative projects to succeed, risks must be managed.

The purpose of this research was to examine how innovative projects differ from other types of projects (conventional projects). The research has shown that different types of projects are managed differently by looking at three different types of projects.

IPM can indeed benefit from looking at how other types of projects are managed, based on their characteristics. Innovative projects exhibit different characteristics and so warrant a different approach when being managed. As more innovative projects are being conducted, the suggested success criteria for innovative projects can be tested and refined using the empirical evidence available from these projects.

The research showed clearly the differences between conventional projects and innovative projects. In conclusion, the research provided ample evidence to support its assumption that innovative projects are different from conventional projects and therefore should be managed differently.

Both theoretical reflection and empirical studies are needed to understand what the success factors of innovative projects exactly are in practice. This paper has provided theoretical reflection on managing innovative projects as opposed to previous research that has only been dominated by technique-oriented studies often with no clear empirical basis. Further research could focus on investigating clear empirical evidence on managing innovative projects in South Africa. 


\section{REFERENCES}

Atkinson, R. (1999). Project Management: cost time and quality two best guesses and a phenomenon it's time to accept other success criteria, International Journal of Project Management, 17(6), 337342.

Belassi, W. \& Tukel, O.I. (1996). A new framework for determining critical success/failure factors in projects, International Journal of Project Management, 17(3), 139 -145.

Berggren,C., Järkvik, J. \& Söderlund, J.(2008). Lagomizing, Organic Integration, and Systems Emergency Wards: Innovative Practices in Managing Complex Systems Development Projects, Project Management Journal, 39

Besner, C. \& Hobbs, B. (2008). Discriminating Contexts and Project Management Best Practices on Innovative and Noninnovative Projects, Project Management Journal, 39

Bogliacino, F. \& Pianta, M. (2010). Profits, R\&D and innovation: a model and a test, ITPS working paper on corporate R\&D and innovation, Publications Office of the European Union, Luxembourg.

Boland, R. \& Lyytinen, K. (2007). Wakes of innovation on projects networks, Organisation Science.

Chesbrough, H.W. (2003). The era of open innovation, MIT Sloan Management Review, 44(3), 35-38.

Clements, J.P. \& Gido, J. (2009). Effective Project Management, $4^{\text {th }}$ Edition, South-Western: Mason, $\mathrm{OH}, \mathrm{US}$.

Cooke-Davies, T. (2002). The 'real' success factors on projects, International Journal of Project Management, (20), $185-190$.

Cooper, R.G. (2006). Managing technology development projects, Research Technology Management, 49(6), 23-31.

Cozijnsen, A.J., Vrakking, W.J. \& van ljzerloo, M. (2000). Success and failure of 50 innovation projects in Dutch companies, European Journal of Innovation Management, 3(3), 150-159.

Drucker, P.F. (2002). The discipline of innovation, Harvard Business Review, 80, 95-103.

Dvir, D., Lipovetsky, S., Shenhar, A. \& Tishler, A. (1998). In search of project classification: a non-universal approach to project success factors, Research Policy, 27,915-935.

Edquist, C. (2010). Systems of Innovation Perspectives and Challenges, African Journal of Science, Technology, Innovation and Development, 2(3), 14-45.

Fagerberg, J. (2004). Innovation: a guide to the literature, Oxford Handbook of Innovation, Oxford University Press: Oxford, UK.

Filippov, S. \& Mooi, H. (2010). Innovation Project Management: A Research Agenda, RISUS Journal on Innovation and Sustainability, 1 (1).

Ireland, R.D. \& Hitt, M.A. (1999). Achieving and maintaining strategic competitiveness in the 21st century: the role of strategic leadership. Academy of Management Executive, 13, 43-57.

Jacoby, R. \& Rodriguez, D. (2007). Innovation, Growth, and Getting to Where You Want to Go. Design Management Review, 18(1), 10-15.

Kavanagh, D. \& Naughton, E. (2009). Innovation and Project Management - Exploring the links, PM World Today (e-Journal), Featured Paper April 2009. 11(4).

Kimberling, E. (2006). 7 critical success factors that make your ERP or IT project successful. Retrieved October 19, 2011, from http://it.toolbox.com/blogs/erp-roi/7-critical-success-factors-to-make-yourerp-or-it-project-successful-12058

Korecky, M. \& Trkovsky, V. (2009), Risk Analysis and Management of Projects with High Innovation Content, PICMET 2009 Proceedings. 
Lechler, T. \& Grace, E. (2007). Successful management of highly innovative and urgent projects: Analysing project management practices to reveal strategic directions, PICMET 2007 Proceedings.

Martin, P. \& Tate, K. (2001). Getting started in Project Management, John Wiley \& Sons (e-book).

Murray, J.P. (2001). "Recognizing the Responsibility of a Failed Information Technology Project as a Shared Failure", Information Systems Management, 18 (2), 25-29.

Nicholas, J. \& Hidding, G. (2010). Management Principles Associated With IT Project Success, International Journal of Management and Information Systems, 14(5), 147-156.

Organisation for Economic Co-operation \& Development (OECD), (1993). The measurement of scientific and technical activities, OECD Publication: Paris.

Organisation for Economic Co-operation \& Development (OECD), (2005). Oslo Manual: Guidelines for collecting and interpreting innovation data, OECD Publication: Paris.

Rad, P. \& Levin, G. (2002). The Advanced Project Management Office, St. Lucie Press: Boca Raton, Florida, US.

Robertson, M., Galliers, R., Ostrick, C. \& Scarbrough, H. (2011). Managing interactive innovation: From project management to process mobilisation, Proceedings of the $44^{\text {th }}$ International Conference on System Sciences - 2011.

Rockart, J.F. (1979). Chief executives define their own data needs, Harvard Business Review, 57(2), 8193.

Sauer, C. \& Reich, B. H. (2009). 'Rethinking IT project management: Evidence of a new mindset and its implications'. International Journal of Project Management, (27), 182-193.

Schroll, A. \& Mild, A. (2011). Europe Open innovation modes and the role of internal R\&D: An empirical study on open innovation adoption in Europe, European Journal of Innovation Management, 14 (4), 475-495.

Schumpeter, J. (1934). The Theory of Economic Development, Harvard University Press: Cambridge, MA, US.

Schwalbe, K. (2009). Introduction to Project management, $2^{\text {nd }}$ Edition, Course Technology: Boston, MA, US.

Science \& Engineering Indicators, (2010). National Science Board, Washington, DC, US.

Shenhar, A. J. \& Dvir, D. (2007). Reinventing Project Management: The Diamond Approach to Successful Growth and Innovation, Harvard Business School Press, Boston, MA, US.

Shokri-Ghasabeh, M. and Kavoousi-Chabok, K. (2009). Generic Project Success and Project Management Success Criteria and Factors: Literature Review and Survey. WSEAS, Transactions on Business and Economics 6(8): 456-468.

Steyn, H. (2009). The Evolution of Project Management, The Project Manager (magazine), A PMSA Publication, September 2009.

Thomas, G. \& Fernańdez, W. (2008). "Success in IT projects: A matter of definition?" International Journal of Project Management, 26,733-742.

Tidd, J. Bessant, J. \& Pavitt, K. (2001). Managing Innovation: Integrating Technological, Market \& Organisational Change, $2^{\text {nd }}$ Edition. John Wiley: Chichester, UK.

Turner, J.R. (1999). Gower Handbook of Project Management, $4^{\text {th }}$ Edition, Gower Publishing: Aldershot, UK. 